\title{
"Lifestyle" Muslimah
}

\author{
Rini Rinawati
}

\section{ABSTRACT}

It is always interesting to discuss youth lifestyle. As part of pop culture, youth lifestyle has some features, i.e. standardized culture, having fixed repetitive format, light enjoyable, sentimental, short-lasting, and artificially crafted. Such characteristics are in opposite with other cultural values such as serious, intellectuality, time-respect, and authenticity. In the world of Moslem girl, there is also a strong tendency of being modern and sociable. Mass media and globalization are believed to be the most influential factors. In order to solve the problem, original Islamic learning process such as "madrasah" and "pesantren" are strongly promoted.

Kata kunci: gaya hidup, remaja muslimah, budaya pop

\section{Pendahuluan}

\subsection{Latar Belakang}

Dunia begitu indah, demikian hidup di masa remaja alih-alih masa muda. Yang terbentang di mata remaja hanya ada kesenangan, kemudahan, dan keindahan. Berbicara mengenai remaja, maka akan berbicara mengenai budaya mereka, tentunya tentang gaya hidup (Lifestyles) mereka, yaitu pergaulan, musik, percintaan, fashion, bahasa, dan masih banyak lagi. Barker (2005:421) menjelaskan bahwa salah satu hal yang menjadi ciri dunia pascaperang adalah munculnya dan berkembangnya berbagai bentuk musik, gaya fashion, aktivitas waktu senggang, tarian, dan bahasabahasa yang khas yang diasosiasikan dengan anak muda/remaja. Persoalan kebudayaan anak muda kemudian menjadi bagian penting dalam kajian budaya.

Kalau kita perhatikan mengenai remaja, ternyata remaja zaman sekarang sangat berbeda dengan remaja zaman dulu. Orang bilang, remaja sekarang ini “cangih". Dulu, tidak ada mal-mal yang dijadikan arena jalan-jalan, arena "mejeng", dan arena untuk pertemuan "gaul" para remaja. Dulu, mana ada kafe-kafe yang dijadikan tempat kumpulkumpul para remaja. Inilah salah satu ciri dari budaya populer yang saat ini sedang berkembang di kalangan anak muda.

Gaya hidup, khususnya di kalangan anak muda, menarik disimak, karena gaya hidup secara tidak terasa telah mengemudikan diri kita, khususnya remaja, sejak membuka mata di pagi hari sampai terlelap kembali di malam hari. Pada gilirannya, remaja sebagai masyarakat konsumen menjadi salah satu objek yang empuk bagi industri gaya hidup.

Masyarakat konsumen Indonesia mutahir tampaknya tumbuh beriringan dengan sejarah globalisasi ekonomi dan transformasi kapitalis konsumsi yang ditandai dengan menjamurnya pusat perbelanjaan bergaya semacam shopping mall, industri waktu luang, industri mode atau fashion, industri kecantikan, industri kuliner, industri 
gosip, kawasan huni mewah, real estate, dan sebagainya (Chaney, 2003:8).

Hal ini menjadikan kaum muda Indonesia khususnya Muslimah, terpengaruh oleh trend tersebut. Pada gilirannya, bagi sejumlah kawula muda, gaya hidup enak dengan segala kemudahan sudah menjadi kebiasaan yang makin mengakar. Di samping itu, kita dapat melihat tayangantayangan televisi yang banyak mengungkap budaya pop ini dari mulai fashion, penampilan, sampai pada bahasa. Lihat saja sinetron-sinetron yang banyak memperlihatkan bagaimana mode berpakaian artis-artis kita yang pada gilirannya ditiru oleh para remaja kita. Lihat pula, misalnya, bagaimana bahasa yang dipergunakan dalam tayangan kita, kemudian tidak lama juga beredar di kalangan remaja. Dan masih banyaknya lagi sisi tayangan-tayangan televisi yang menampilkan budaya pop, kemudian merebak, bahkan menjadi trend dilakangan remaja kita.

Indonesia dengan penduduk yang sebagian besar Muslim, tentunya tidak luput dari serbuan budaya massa (budaya populer). Di kalangan umat Islam mulai marak iklan dan industri jasa dalam bidang spiritualisme, contohnya pada fashion. Hal ini ditandai dengan menjamurnya konter-konter berlabel exlusive Moslem fashion. Bahkan, saat ini mulai berkembang factory oulet khusus busana Moslem.

Sementara itu, maraknya penerbitan majalah anak muda Islam (khususnya Muslimah) nyaris tidak jauh berbeda sensibilitasnya dengan majalah anak muda umumnya. Yang ditawarkan adalah mode, shopping, soal gaul, seks, dan pacaran yang dianggap sebagai "Islami”. Slogan yang ditawarkannyapun seperti halnya untuk anak muda umumnya; "jadilah Muslimah yang gaul dan smart", atau "jadilah Muslim yang cerdas, dinamis, dan trend", atau "jadilah cewek Muslimah yang proaktif dan ngerti fashion". Demikian pula dengan tayangan televisi melalui berbagai sinetron yang menampilkan potret remaja yang berbusana minim. Banyak artis dan penyanyi yang gemar menampakkan aurat, dan lain lain.

Dengan adanya fenomena tersebut, maka remaja Muslimah sebagai masyarakat konsumen menjadi sasaran yang empuk. Sebagai contoh, lihat saja industri mode (fashion) yang terus bermunculan untuk memenuhi gaya hidup remaja Muslimah dalam urusan mode. Selain mode, kita dapat melihat pula di mal-mal tentang remaja muslimah yang banyak berkeliaran ("mejeng"), demikian pula di kafe-kafe. Dengan kata lain, remaja Muslimah dalam hal gaulpun tidak ketinggalan dari remaja umumnya. Dari beberapa fenomena di atas, menarik untuk mengkaji mengenai: "Gaya Hidup (lifestyles) remaja Muslimah.”

\subsection{Identifikasi Masalah}

Dari fenomena yang diuraikan sebelumnya, maka masalah diidentifikasi sebagai berikut:

(1) Bagaimana gGaya hidup remaja Muslimah?

(2) Bagaimana globalisasi media massa turut mempengaruhi terhadap gaya hidup ini?

(3) Upaya apa atau "tuntunan" apa yang dapat diberikan kepada remaja/anak muda kita dalam globalisasi gaya hidup ini?

\subsection{Tujuan Penulisan}

Tujuan dari penulisan masalah ini adalah:

(1) Untuk mengetahui gaya hidup remaja Muslimah.

(2) Untuk mengetahui media massa pada era globalisasi saat ini mempengaruhi gaya hidup remaja muslimah.

(3) Untuk mengetahui upaya atau "tuntunan" yang dapat diberikan kepada remaja muslimah kita dalam globalisasi gaya hidup ini.

\subsection{Kegunaan Penulisan}

Hasil dari pengkajian mengenai masalah ini diharapkan mempunyai nilai guna dari dua segi, yaitu sebagai berikut:

(1) Kegunaan Praktis:

(a) Memberikan masukan bagi para remaja muslimah dalam mencermati budaya pop yang sedang trend.

(b) Memberikan masukan bagi para orangtua dan para pendidik dalam membimbing remaja muslimah dari serbuan budaya pop yang saat ini sedang trend.

(2) Kegunaan Teoretis: Memberikan sumbangan pikiran bagi 
perkembangan teori-teori komunikasi khususnya kajian budaya.

\section{Tinjauan Teoretis}

\subsection{Komunikasi dan Budaya}

Sebagai makhluk yang tidak dapat hidup sendiri, manusia memerlukan orang lain. Oleh karena itu, manusia memerlukan komunikasi untuk berinteraksi dengan manusia lainnya. Manusia tidak dapat tidak berkomunikasi atau "we can not not communicate".

Setiap komunikasi yang dilakukan oleh manusia akan berpotensi sebagai komunikasi dengan perbedaan budaya (komunikasi antarbudaya), karena setiap manusia merupakan produk sebuah budaya. Ketika Anda sebagai orang yang katanya berasal dari budaya "kuno" berkomunikasi dengan anak remaja, yang katanya juga, dari budaya "masa kini" atau budaya "kontemporer", maka pada saat itu Anda sedang melakukan komunikasi antarbudaya. Terlebih dalam era globalisasi ini, di mana tingkat mobilisasi penduduk dunia sedang mencapai puncaknya dalam keseharian akan banyak berkomunikasi dengan orang-orang dari budaya yang berbeda. Kemudian para ahli menganjurkan bahwa kita perlu memahami tentang budaya dalam berkomunikasi.

Komunikasi dan budaya menjadi bagian penting dari masyarakat kontemporer, dikarenakan komunikasi dan budaya merupakan dua hal yang tidak dapat dipisahkan bagaikan dua sisi dari satu mata uang. Pada gilirannya, komunikasi dan realitas (budaya) saling berhubungan. Fiske menjelaskan komunikasi merupakan proses yang tertanam dalam kehidupan kita sehari-hari yang menginformasikan cara kita menerima, memahami, dan mengonstruksi pandangan kita tentang realitas dan dunia (2004:x).

Selanjutnya, Fiske menegaskan bahwa komunikasi merupakan sentral bagi kehidupan manusia, karena tanpa komunikasi, kebudayaan dari jenis apapun akan mati. Sebaliknya, cara-cara kita berkomunikasi, keadaan-keadaan komunikasi kita, bahasa dan gaya bahasa merupakan respon terhadap dan fungsi komunikasi. Oleh karena itu, Komunikasi pun terikat budaya. Benar kata Ed- ward T. Hall (dalam Mulyana,1998; vi) bahwa "culture is communication" dan "communication is culture".

James W. Carey memberikan definisi kultural terhadap komunikasi, yaitu "Communication is a symbolic process whereby reality is produced, maintained, repaired and tranformed" (dalam Fiske,2004:x).

Clifford Geertz merumuskan kebudayaan sebagai "pola nilai dalam bentuk simbol-simbol yang diwariskan secara historis, suatu acuan wacana yang dinyatakan dalam bentuk perlambang lewat mana masyarakat berkomunikasi, meneruskan, dan mengembangkan pengetahuan mereka atas kehidupan". (dalam Jurnal ISKI,1997:85)

Melihat pada penjelasan ahli mengenai komunikasi dan mengenai budaya, maka jelaslah bahwa terdapat hubungan yang erat antara komunikasi dan budaya. Larry A. Samovar dan Richard E. Porter mengemukakan enam unsur budaya yang secara langsung mempengaruhi komunikasi, yaitu:

(a) Kepercayaan (beliefs), nilai (Values), dan sikap (attitued)

(b) Pandangan dunia (wordview)

(c) Organisasi sosial (social organization)

(d) Tabiat manusia (human nature)

(e) Orientasi kegiatan (activity orientation)

(f) Persepsi tentang diri dan orang lain (dalam Mulyana,1998:197).

\subsection{Budaya Populer ("Pop Culture")}

Kalau berbicara mengenai budaya populer (pop culture), maka kita akan dihadapkan pada sekian banyak istilah lain seperti budaya massa, budaya dangkal, budaya konsumen, budaya komersial, dan lainnya lagi. Memang, mencermati budaya populer selanjutnya sering disebut sebagai budaya pop dapat dipetakan berdasarkan bagaimana budaya pop itu diidentifikasikan melalui gagasan budaya massa, sehingga lahirlah teori budaya massa. Maraknya komersialisasi budaya dan hiburan yang dipamerkan lewat media massa mempengaruhi perkembangan budaya massa yang pada akhirnya perkembangan budaya pop. 
Dalam kajian teori budaya massa, sejarah gagasan budaya pop secara gamlang disampaikan oleh William, merujuk pada "pergeseran sudut pandang" antara abad delapan belas dan abad sembilan belas, dia menulis:

Populer dipandang dari sudut pandang orang dan bukannya dari mereka yang mencari persetujuan atau kekuasaan atas mereka. Sekalipun demikian, pengertian awal tidaklah mati. Budaya populer bukan diidentifikasi oleh rakyat tapi oleh orang lain, dan masih menyandang dua makna kuno: jenis karya interior (sastra populer, pers populer, yang dibedakan dengan pers berkualitas); dan karya yang secara sengaja dibuat agar disukai orang (jurnalisme populer dibedakan dengan jurnalisme demokratik, atau hiburan populer); maupun pengertian modern yang disukai banyak orang, yang tentunya pada banyak kasus bertumpang tindih dengan pengertian lama. Pengertian mutahir budaya populer sebagai kebudayaan yang sebenarnya dibuat oleh orangorang untuk kepentingan mereka sendiri yang sama sekali berbeda dengan semua pengertian di atas (dalam Strinati, 2004:3).

Terdapat tiga tema yang saling terkait dalam karya Williams tersebut, yaitu: pertama adalah apa atau siapa yang menentukan budaya populer. Kedua, berkenaan dengan pengaruh komersialisasi dan industrialisasi terhadap budaya pop. Dan yang terakhir menyangkut peran ideologis budaya pop.

Dengan demikian, budaya populer atau budaya pop adalah budaya massa, yang dihasilkan melalui teknik-teknik industrial produksi massa dan dipasarkan untuk mendapatkan keuntungan kepada khalayak konsumen massa. Atau sebaliknya, budaya massa adalah budaya populer, yang diproduksi untuk pasar massal.

Oleh karena itu, menurut teori ini, budaya massa alih-alih merupakan budaya pop, yaitu sebuah budaya standar, memiliki rumusan, berulang dan bersifat permukaan, yang mengagungkan kenikmatan remeh, sentimental, sesaat dan menyesatkan dengan mengorbankan nilai-nilai keseriusan, intelektualitas, penghargaan atas waktu, dan autentisitas.

Sebagai konsekuensi, maka dengan perkembangan budaya pop ini akan memberi ruang yang semakin sempit kepada kebudayaan yang tidak dapat menghasilkan uang, yang tidak dapat diproduksi secara massa, seperti kesenian dan budaya rakyat. Hal ini sejalan dengan apa yang dikemukakan McDonald yang mengeluhkan apa yang dia sebut sebagai "penyebaran lumpur budaya massa". McDonald mengungkapkan,

"Hal ini merupakan sebuah kebudayaan yang menurunkan martabat dan bersifat remeh serta membatalkan realitas-realitas mendalam, dan juga kenikmatan sederhana dan spontan. Massa yang dirusak oleh beberapa generasi semacam ini pada gilirannya menuntut produk-produk kultural yang remeh dan menyenangkan" (dalam Strinati, 2004:16).

Selanjutnya, teori budaya massa menjelaskan bahwa kebudayaan ini kurang memiliki tantangan dan rangsangan intelektual, lebih cenderung pada pengembaraan fantasi tanpa beban, di mana budaya massa ini menciptakan respons-respons emosional maupun sentimentalnya sendiri dan bukannya meminta khalayaknya untuk menggunakan pikiran mereka, sehingga dalam budaya massa ada kecenderungan menyederhanakan dunia nyata dan mengabaikan persoalan-persoalannya.

\subsection{Gaya Hidup ("Lifestyles")}

Gaya hidup mulai marak sejak 1990-an, dan tampaknya sampai saat ini persoalan gaya hidup menjadi hal yang tidak bisa dianggap sepele. Tak bisa dipungkiri, dengan adanya globalisasi industri media dari mancanegara dengan modal besar yang mulai marak masuk ke tanah air, tentunya membuat serbuan gaya hidup lewat industri iklan dan televisi sampai ke ruang-ruang kita yang paling pribadi, dan bahkan ke relung-relung jiwa kita yang paling dalam.

Gaya hidup merupakan ciri sebuah dunia modern, atau bisa disebut sebagai modernitas. Karena, dalam dunia modern gaya hidup akan membantu mendefinisikan sikap, nilai-nilai, dan menunjukkan kekayaan serta posisi sosial kita. Maka, tampaklah bahwa gaya hidup dianggap merupakan proyek yang lebih penting daripada aktivitas waktu luang. 
Kata "gaya" dalam bahasa Indonesia merupakan padanan kata "style" dalam bahasa Inggris, yang berasal dari bahasa Yunani "stilus", yang artinya alat tulis, atau tulisan tangan. Meyer Schapiro mendefinisikan gaya sebagai "bentuk yang konstan dan kadang unsur-unsur, kualitaskualitas, dan ekspresi yang konstan dari perseorangan maupun kelompok." Alvin Toffler mendefinisikan gaya (hidup), yaitu "alat yang dipakai oleh individu untuk menunjukkan identitas mereka dengan subkultur-subkultur tertentu" (dalam Ibrahim, 1997:165).

Chaney (2003:91) memberikan penjelasan bahwa "gaya hidup adalah suatu cara terpola dalam penggunaan, pemahaman, atau penghargaan artefak-artefak budaya material untuk menegosiasikan permainan kriteria status dalam konteks sosial." Dari pemahaman tersebut jelas bahwa peredaran gaya hidup merupakan makna simbolik dari artefak-artefak tersebut, artinya apa yang terlihat mempresentasikan tentang identitas mereka. Dengan demikian, gaya hidup selanjutnya merupakan cara-cara terpola dalam menginventasikan aspek-aspek tertentu kehidupan sehari-hari dengan nilai sosial atau simbolik. Artinya, gaya hidup adalah cara bermain dengan identitas.

Kajian mengenai gaya hidup dapat ditarik sampai kepada teori tentang presentasi diri (impression management) dalam "dramaturgi" dari Erving Goffman. Dalam gaya hidup, penampilan adalah segalanya, hal ini sejalan dengan presentasi diri yang selalu dilakukan oleh manusia dalam kehidupan sehari-harinya. Erving Goffman dalam karyanya, The Presentation of Self in Everyday Life, mengemukakan bahwa kehidupan sosial, terutama, terdiri dari penampilan teatrikal yang diritualkan, di mana kita bertindak seolah-olah di atas sebuah panggung sandiwara.

Goffman tertarik pada serangkaian tindakan individu yang dilakukan atau dipertunjukkan (show) bagi orang lain, sehingga menampilkan kesan-kesan (impression) tertentu. Dalam rangka pertunjukan (show) diri ini, seseorang memiliki dua wilayah, yaitu:

(1) Wilayah Depan (front region), merujuk pada peristiwa sosial yang memungkinkan individu bergaya atau menampilkan peran formalnya. Dalam wilayah depan inilah gaya hidup seseorang akan ditampilkan.

Panggung depan (front region), terdiri dari:

(a) Front Pribadi (personal front), yang terdiri dari alat-alat yang dapat dianggap sebagai perlengkapan yang dibawa sang aktor, dan juga bahasa (verbal dan nonverbal).

(b) Setting, yaitu situasi fisik yang harus ada ketika sang aktor melakukan pertunjukan seperti; ruang periksa untuk dokter, ruang kuliah untuk guru, dsb

(2) Wilayah Belakang (back stage), bagian belakang, yaitu tempat di mana para aktor mempersiapkan diri, bersantai atau berlatih dan biasanya tidak diketahui oleh khalayaknya.

Berdasarkan bagaimana presentasi diri dalam rangka menanamkan kesan-kesan (impression) tertentu merupakan salah satu faktor yang mempengaruhi gaya hidup seseorang. Seorang artis harus tampil bak Cinderela ketika berangkat ke pesta sang Pangeran, dan menyembunyikan kehidupan yang sebenarnya. Hal ini dilakukan karena khalayak menuntutnya demikian. Oleh karena itu, gaya hidup para artis terlihat bergelimang kemewahan. Sementara itu, berbahagialah sang pelukis, karena tidak ada harapan-harapan dari khalayak untuk tampil penuh gebyar. Bahkan sebagai seniman dia mendapatkan "prevelese" untuk berulah sedikit nyentrik. Artinya, toleransi yang diberikan masyarakat lebih besar dan longgar dalam mempresentasikan dirinya.

Dengan demikian, gaya hidup seorang akan berbeda sesuai dengan bagaimana presentasi diri yang harus ditampilkan di atas panggung. Demikian pula remaja atau anak muda, mereka punya gaya hidup sendiri sebagai identitas keremajaannya. Memang, gaya hidup sebagai pembeda kelompok akan muncul dalam mayarakat yang terbentuk atas dasar stratifikasi sosial. Setiap kelompok dalam stratum sosial tertentu akan memiliki gaya hidup yang khas.

Oleh karena itu, gaya hidup, menurut Siregar (dalam Ibrahim, 1997:207), hanya dapat dibicarakan jika kita mau melihat kehadiran kelompok dalam 
'kelas"'-nya masing-masing. Dan karena gaya hidup merupakan simbol prestise suatu kelas tertentu, penyebarannya melalui komunikasi massa akan menembus batas-batas stratifikasi sosial. Pada saat itulah kita akan menempatkan gaya hidup sebagai suatu kebudayaan massa (populer) yang kehilangan ekslusivitas kelas sosial tertentu.

\subsection{Remaja atau Anak Muda}

Pada suatu waktu kita melihat sekumpulan orang yang berusia 17 tahun di sebuah mal, dan kita menyebut mereka adalah sekumpulan remaja/ anak muda yang sedang ber-“jalan-jalan." Di kesempatan lain, kita melihat seseorang yang berusia 40 tahun, namun dari segi penampilan atau gaya, terlihat sama dengan anak-anak SMA, dan kita menyebutnya sebagai berjiwa muda.

Definisi tentang remaja/anak muda, ternyata ambigu. Para ahli dalam kajian budaya menyatakan bahwa konsep anak muda/remaja tidak memiliki makna yang universal. Hal ini dikarenakan dalam mendefinisikan konsep remaja/anak muda akan berkaitan dengan sisi biologis, sisi psikologis, dan juga dari sisi kultural. Remaja atau sering pula disebut anak muda, sebetulnya tidak mempunyai tempat yang jelas. Ia tidak tergolong anak-anak, tetapi ia tidak termasuk golongan orang dewasa. Remaja/anak muda ada di antara masa kanak-kanak dan orang dewasa. Oleh karena itu, masa remaja menunjukkan dengan jelas sifat-sifat masa transisi atau peralihan, karena remaja belum memperoleh status orang dewasa tetapi tidak lagi memiliki status kanak-kanak.

Menurut Monks, Knoers, dan Haditono (2004:261), masa remaja yang kurang lebih ada pada rentang usia 12 sampai 18 tahun, memiliki perkembangan sebagai berikut:

(1) perkembangan aspek-aspek biologis;

(2) menerima peranan dewasa berdasarkan pengaruh kebiasaan masyarakat sendiri;

(3) mendapatkan kebebasan emosional dari orang tua dan/atau orang dewasa lain;

(4) mendapatkan pandangan hidup sendiri

(5) merealisasi suatu identitas sendiri dan dapat mengadakan partisipasi dalam kebudayaan pemuda sendiri.
Sementara itu, menurut Sibley, usia fisik yang dipakai dalam mendefinisikan remaja/anak muda itu fleksibel sesuai dengan budayanya masingmasing, karena setiap budaya punya batasan yang berbeda-beda untuk kategori anak-anak. Dengan demikian, anak muda lebih tepat dilihat sebagai sekumpulan klasifikasi kultural yang kompleks dan terus bergeser yang dicirikan oleh adanya perbedaan dan keragaman. Dari pandangan ini memunculkan beberapa asumsi atau klasifikasi dari anak muda, menurut Cohen, yaitu sebagai berikut: (1) Anak muda adalah sebuah kategori tunggal, dengan karakteristik-karakteristik psikologis dan kebutuhan-kebutuhan sosial tertentu yang dimiliki oleh suatu kelompok usia.

(2) Masa muda merupakan tahap perkembangan yang bersifat formatif(membentuk), masa di mana sikap dan nilai-nilai terpatri pada ideologiideologi yang akan menetap demikian selama hidup.

(3) Transisi dari ketergantungan masa anak-anak menuju otonomi masa dewasa normalnya melibatkan fase pemberontakan, yang merupakan tradisi kultural yang diwariskan dari generasi ke generasi.

(4) Anak muda di masyarakat modern mengalami kesulitan untuk menjalani transisi serta butuh pertolongan, saran, dan dukungan profesional (dalam Barker, 2005:423).

\section{Pembahasan}

\subsection{Gaya Hidup Remaja Muslimah}

Indonesia merupakan negara yang penduduknya sebagian besar beragama Islam, di mana dari yang sebagian besar itu porsi terbanyak adalah wanita. Dengan demikian membicarakan gaya hidup remaja Muslimah menjadi topik pembicaraan yang menarik, karena dunia wanita, khususnya remaja, menjadi dunia yang sering manjadi komoditas industri gaya hidup. Selanjutnya membicarakan gaya hidup remaja muslimah akan menyangkut pada pergaulan, fashion atau penampilan.

Penampilan bagi remaja merupakan ciri yang khas, karena budaya anak muda sangat identik 
dengan penampilan sebagai representasi dari identitas diri. Hal ini sejalan dengan apa yang dijelaskan David Chaney (2003:15) bahwa penampilan dalam industri gaya hidup adalah segalanya. Oleh karena itu tubuh/diri dalam kehidupan sehari-hari menjadi objek atau proyek benih penyemaian gaya hidup. "Kamu bergaya, maka kamu ada" adalah ungkapan yang cocok untuk melukiskan kegandrungan remaja muslimah kita terhadap gaya hidup. Tidak heran industri gaya hidup sebagian besar adalah industri penampilan.

Ciri dari seorang Muslimah dapat dilihat dari pakaian Muslimahnya. Dalam gelombang gaya hidup ini cara berpakaian dari para Muslimah ini juga terkena budaya populer. Memang, agar tidak dikatakan melanggar aturan agama, terutama perintah berjilbab para remaja Muslimah mengontekskan jilbab dengan dunia remaja melalui budaya "gaul”-nya, lahirlah "kerudung gaul, jilbab gaul, atau jilbab gaya selebritis" dan menjadi trend remaja Muslimah yang tidak mau ketinggalan mode. Ciri khas jilbab ini kerudung dililitkan ke leher dengan baju dan celana atau rok ketat, sehingga membentuk hampir seluruh anggota badan. Kini perempuan tidak lagi mengenakan jilbab dengan pakaian yang longgarlonggar saja, yang tidak menunjukkan lekuk tubuh, tetapi juga dengan kaos atau hem lengan panjang yang ketat, atau juga celana jins yang kadang juga pas dengan lekuk tubuhnya.

Dalam hal berpakaian pun sekarang banyak Muslimah yang dengan santainya memakai pakaian yang serba minim, ketat, dan transparan ala artis MTV. Hal ini dikarenakan dunia mode menawarkan berbagai macam produk yang membuat mereka tergoda untuk memilikinya, sehingga muncullah persepsi yang salah di kalangan Muslimah di mana kalau tidak mengikuti trend yang terbaru, berarti mereka bukan anak muda yang "gaul". Terbentuklah ideologi "beragama tetapi tetap trendi" atau "biar religius tetapi tetap modis".

Untuk memenuhi keinginan para Muslimah dalam hal fashion ini, peragaan dan lomba busana Muslim mulai sering diadakan. Bahkan setiap tahun para perancang yang mengkhususkan diri pada busana Muslim juga mengeluarkan trend "baju Muslim" untuk tahun berikutnya, sama seperti perancang-perancang busana lain yang setiap tahun juga mengeluarkan rancangan trend busana musim gugur, musim panas, musim dingin dan lain-lain.

Dari berbagai fenomena di atas, tidak mengherankan kalau kemudian lahir "budaya Barbies" yang menjadi trend setter bagi penampilan remaja Muslimah saat ini. Tampaknya, bagi para Muslimah urusan "tampangisme" atau "wajahisme" (lookism/faceism) kini menjadi persoalan serius dalam perburuan kecantikan dan untuk selalu tampil yang tercantik, tidak hanya dipentas fashion, tapi juga dalam kehidupan seharihari.

Ini merupakan gejala paling mutahir di Indonesia, bagaimana seorang Muslimah dilatih untuk terobsesi dengan persoalan gaya hidup "Barbies" yang mendewakan penampilan, sehingga salonsalon selalu ramai dipenuhi remaja putri, apakah itu untuk merawat wajah, tubuh, rambut, bahkan sampai ke kuku tangan maupun kaki. Tak heran, industri jasa yang memberikan layanan untuk mempercantik penampilan (wajah, kulit, tubuh, rambut) telah dan akan terus tumbuh menjadi big business. Lahirlah apa yang saat ini kita kenal dengan "salon Muslimah".

Dalam masyarakat modern saat ini, di mana gaya hidup menjadi sebuah ciri, setiap orang dituntut memainkan dan mengontrol peranan mereka sendiri. Dengan demikian, gaya pakaian, dandanan rambut, juga segala macam asesoris yang menempel, adalah bagian dari pertunjukan identitas dan kepribadian diri para remaja. Hal ini sejalan dengan ciri perkembangan remaja itu sendiri yang dikemukakan Monks, Knoers, dan Haditono (2004:261), yang menjelaskan bahwa para remaja punya keinginan untuk merealisasi suatu identitas sendiri dan dapat mengadakan partisipasi dalam kebudayaan pemuda sendiri.

Teori tentang presentasi diri (Impression Management) dalam "Dramaturgi" dari Erving Goffman mengisyaratkan pula bahwa melalui gaya hidupnya remaja Muslimah berusaha menampilkan simbolsimbol tertentu untuk memperoleh kesan-kesan 
tertentu. Hal ini sesuai dengan penjelasan dari Chaney yang menyatakan bahwa peredaran gaya hidup merupakan makna simbolik, di mana apa yang terlihat akan merepresentasikan suatu identitas tertentu. Oleh karena itu, gaya hidup sering dihubungkan dengan status dan menunjukkan citra seseorang. Dengan demikian, apa pun yang berkaitan dengan kehidupan manusia merupakan simbol-simbol yang akan menyampaikan citra tertentu (Chaney, 2003:91).

Selanjutnya, dalam hal bergaul para remaja Muslimah ini telah mengikuti arus budaya pop yang sedang trend. Dengan menjamurnya pusat perbelanjaan bergaya semacam shopping mall, kafe-kafe, dan sebagainya, menjadikan kaum muda, khususnya Muslimah menjadikan tempat tersebut sebagai ajang berkumpul dan bergaul. Mulailah bermunculan konter-konter berlabel "exclusive Moslem fashion", "cafe Muslimah" dan sebagainya, sebagaimana telah menjamurnya "salon Muslimah". Pada gilirannya bagi sejumlah remaja muslimah, gaya hidup enak dengan segala kemudahan dan kesenangan sudah menjadi kebiasaan yang makin mengakar.

Memang, dengan semakin menjamurnya shopping mall, telah melahirkan gaya hidup baru bagi muslimah kita, yaitu "shopaholic woman" yang, meminjam istilah Yasraf Amir Piliang, shopping mall dalam era globalisasi gaya hidup tidak lagi sekadar "desa global", akan tetapi kini sudah menjadi "desa fantasi global". Shopping mall lewat komoditas yang ditawarkannya telah mentranspormasikan kegiatan belanja yang sebelumnya semata-mata kegiatan transaksi jualbeli, menjadi suatu kegiatan waktu senggang yang menjanjikan kesenangan dan fantasi. Kebudayaan belanja telah menjadi satu gaya hidup di kalangan Muslimah pada saat ini.

\subsection{Pengaruh Media Massa terhadap Gaya Hidup Remaja Muslimah}

Kontribusi media bagi perkembangan gaya hidup para remaja Muslimah sangatlah besar, dikarenakan menjamurnya media massa. Saat ini, kita hidup dengan berlimpahnya informasi. Hal ini tidak lain karena "ledakan informasi" yang bertubi- tubi dibawa media massa ke dalam rumah kita.

Televisi menjadi sebuah "kotak ajaib" yang diletakkan begitu khusus di ruang keluarga. Tidak heran kalau Gerbner menyebut tayangan televisi sebagai "agama baru" yang menggantikan agama tradisional. Lihat saja, misalnya, bagaimana sinetron-sinetron anak muda menampilkan gaya hidup remaja mengenai pergaulan, musik, percintaan, fashio, bahasa, dan masih banyak lagi, sehingga, melalui media massa anak muda menjadi mengetahui trend gaya hidup yang sedang terjadi.

Semua hal yang dipertontonkan oleh televisi melalui tayangannya, seperti gaya pakaian (fashion) serta asesoris perlengkapannya lebih dari sekadar demontrasi penampilan, melainkan demontrasi ideologi. Sekaligus menunjukkan bahwa globalisasi informasi melalui televisi berperan besar dalam penyebaran gaya hidup ini.

Sekarang banyak sekali tayangan-tayangan yang memicu para Muslimah untuk meniru cara berpakaian yang tidak Islami. Tidak sedikit sinetron yang menampilkan potret remaja yang berbusana minim. Banyak artis dan penyanyi yang gemar menampakkan aurat. Semua tontonan itu membuat para Muslimah terpengaruh oleh sikap dan perilaku yang akan mejerumuskan mereka ke jurang kehancuran agama, moral, dan budi pekerti. Media massa yang kerap disebut sebagai cermin dari masyarakatnya, dalam kebudayaan populer ini sebagai cermin tidak memantulkan kenyataan, namun justru lebih banyak merefleksikan bayangan-bayangan yang diinginkan oleh masyarakat tersebut.

Menurut Chaney (2003:10), para pemikir keagamaan mutahir harus mulai melihat bahwa sensibilitas keagamaanpun mulai mengalami "komodifikasi" (menjadi komoditas) dipentas media massa. Ketika kerudung, jilbab, gamis, dan baju koko (dengan berbagai model, pola, corak dan warna) kian menjadi salah satu ikon gaya hidup dalam fashion, dan mulai menjadi bisnis besar, serta banyak dipakai para artis dalam dunia hiburan seperti sekarang ini, maka sebetulnya di kalangan tertentu muncul upaya, disadari atau tidak, untuk memberikan label "Islamisasi" dalam perilaku konsumtif di dunia mode dan shopping. 
Begitu pula dengan perkembangan industri penerbitan khusus remaja saat ini telah menjadi ladang persemaian gaya hidup. Banyak majalah anak muda yang menawarkan gaya hidup di seputar perkembangan trend busana, problem gaul, pacaran, shopping, dan acara mengisi waktu senggang yang jelas perlahan tapi pasti akan ikut membentuk budaya kawula muda (youth culture) yang berorientasi gaya hidup fun.

Sampai tahap ini, kita bisa melihat adanya hubungan yang kompleks antara tubuh, fashion, gaya dan penampilan, serta identitas kepribadian yang ingin dikukuhkan oleh remaja Muslimah sebagai akibat dari pengaruh media dalam pembentukan identitasnya melalui gaya hidup yang ditampilkan.

Memang, pembentukan identitas bukan persoalan sederhana. Ia tidak pernah bergerak secara otonom atau berjalan atas inisiatif diri sendiri, tapi dipengaruhi oleh berbagai macam faktor yang beroperasi bersama-sama. Sebut saja faktor pengaruh ideologi kelompok dan tekanan teman sepermainan sebaya. Di sini, persoalan merek sepatu, atau jenis pakaian, bisa jadi persoalan besar, karena ikut menentukan apakah seseorang dianggap memenuhi syarat untuk dimasukkan dalam kelompok tertentu atau tidak. Faktor-faktor lainnya adalah status sosial. Belum lagi pembombardiran iklan-iklan di media, juga tayangan di tevisi, maupun gambaran di media penerbitan.

Satu hal yang tidak bisa di lupakan adalah unsur kesenangan (pleasure dan fun). Unsur kesenangan ini bisa dipakai untuk menjelaskan dan memahami kelompok anak muda yang mengadopsi, mengonsumsi atau mencampurkan berbagai macam gaya dengan tanpa referensi jelas terhadap makna asalnya. Hanya penampilan semata. Hanya fashion. Tetapi, hal ini tidak berarti mereduksi gaya menjadi sesuatu yang tidak bermakna. Berakhirnya otentisitas bukan berarti kematian makna, peniruanpeniruan, kombinasi, ambil sana-ambil sini ikut membentuk lahirnya makna-makna baru.

\subsection{Tuntunan bagi Remaja Muslimah dalam Globalisasi Gaya Hidup}

Kehidupan masyarakat kontemporer memang menunjukkan persinggungan yang cukup kuat antara budaya pop dan agama. Persinggungan ini, selain memunculkan fenomena masuknya nilai-nilai budaya massa dalam Islam, juga sebaliknya, tampilnya dakwah Islam di media populer, memasuki pula dunia anak muda. Pada titik ini, menunjukkan bagaimana terjadinya gejala kolaborasi antara dua ranah yang selama ini dianggap terpisah, dan bahkan berseberangan. Selain itu, kolaborasi antara budaya pop dan Islam juga menjadi suatu representasi atas perubahan praktik kebudayaan Islam di kalanganMuslimah. Dalam diri mereka, ada saat tertentu yang menunjukkan identifikasi mereka dengan budaya massa anak muda pada umumnya; sementara, ada pula situasi-situasi lain yang dengan jelas menunjuk pada keberadaan diri mereka sebagai muslimah dengan tuntutan ajaran agama Islam.

Mencermati fenomena merebaknya gaya hidup yang telah menyentuh kehidupan para Muslimah, telah menarik perhatian para ulama. Untuk itu, Ustad Ninis menggambarkan bagaimana fenomena gaya hidup di kalangan Muslimah saat ini dengan menjelaskan lewat sisi psikologisnya, bahwa usia remaja sebagai masa "gawat" secara psikologis. Hal ini, karena pengaruh imitasi kepada seseorang atau tokoh idola sangat kuat di usia remaja. Selain itu, ikatan solidaritas teman sebaya lebih kuat. Oleh karena itu, menurut Ninis, "gaul" merupakan pilihan para remaja untuk menyalurkan apsirasinyadan untuk menunjukkan identitasnya. Ketika bersinggungan dengan aturan agama, terutama perintah berjilbab, para remaja kemudian mencoba untuk mengkotekskan jilbab sebagai perintah wajib dengan dunia remaja (gaul). Padahal, yang menjadi persoalannya adalah banyak remaja Muslim tidak memahami hakikat berjilbab (dalam Tiar, www.gontor.or.id).

Dalam al-Quran ayat 31, Surah An-Nur, jelas disebutkan "Dan hendaklah mereka menutupkan kain kerudung ke dadanya." Jadi, untuk batasan model jilbab secara prinsip, sebenarnya sudah jelas dan tidak membutuhkan perdebatan panjang. Dalam al-Qur'an ayat 59, Surah 59, Allah berfirman: "Hai Nabi, katakanlah kepada istri-istrimu, anak-anak perempuan, dan istri-istri orang 
mukmin: Hendaklah mereka mengulurkan jilbabnya ke seluruh tubuh mereka. Yang demikian itu supaya mereka lebih mudah untuk dikenal, karena itu mereka tidak diganggu. Dan Allah adalah Maha Pengampun lagi Maha Penyayang."

Ayat lain yang berkaitan dengan perintah menutup aurat (berjilbab) adalah Surah al-Ahzab ayat 33: "Dan hedaklah kamu tetap di rumahmu dan janganlah kamu berhias dan bertingkah laku seperti orang-orang jahiliyah yang dahulu." Sangat disayangkan pada saat ini banyak kaum Muslimah yang terpengaruh oleh gaya berpakaian ala Barat yang ditularkan di media-media massa. Jika demikian, bisa dibayangkan bagaiman nasib generasi mendatang, ketika para Muslimah yang pada gilirannya nanti akan menjadi ibu sebagai "madrasah pertama" bagi anak-anaknya sudah hilang rasa malunya.

Oleh karena itu, menjadi tugas para orang tua untuk memberikan pemahaman kepada putrinya yang telah mencapai usia belia mengenai kewajiban menutup aurat ini. Dan lingkungan rumah, sangat berpengaruh dalam memberikan contoh yang tepat kepada mereka. Artinya, sang ibu atau kakak perempuan dewasa hendaknya menjadi teladan dalam mengenakan jilbab.

Selanjutnya, bagi para Muslimah tidaklah mudah untuk mengesampingkan derasnya gelombang budaya pop ini, apalagi ditunjang oleh gencarnya dukungan media massa. Oleh karena itu Al-Banna (2004:20) menguraikan dua upaya yang dapat dilakukan untuk membentengi remaja muslimah dalam masyarakat kontemporer (budaya pop) dengan gaya hidup "gaul" yang sedang tren, yaitu;

(1) Adanya upaya pendidikan dan peningkatan budi pekerti menurut ajaran Islam. Hal ini sesuai dengan Al Quran ayat 6 Surat At-Tahrim: "Hai orang-orang yang beriman, peliharalah dirimu dan keluargamu dari api neraka yang bahan bakarnya adalah manusia dan batu. Penjaganya malaikat yang kasar, yang keras, yang tidak mendurhakai Allah terhadap apa yang diperintahkan-Nya kepada mereka dan selalu mengerjakan apa yang diperintahkan."

(2) Perlu memberikan pemahaman mengenai batasan pergaulan antara laki-laki dan perempuan. Islam berpandangan bahwa pergaulan bebas antara laki-laki dan perempuan hanya akan mengundang banyak bahaya yang nyata.

Dengan demikian, sebuah jalan yang dapat dilalui Muslimah dalam mengarungi budaya pop dengan segala trend 'gaul'-nya adalah kembali kepada syariat Islam secara benar. Dan pendidikan di rumah menjadi ujung tombak bagi benteng untuk memperteguh keimanan. Allah telah menegaskan bahwa ketika seorang perempuan berpegang teguh pada nilai-nilai agamanya, maka hal itu bisa mendatangkan kebahagiaan dan ketenangan.

\section{Penutup}

\subsection{Simpulan}

Berdasarkan kajian secara teoretis dan pembahasan fenomena di lapangan yang telah dijelaskan pada uraian sebelumnya, dapat disimpulkan beberapa hal sebagai berikut:

(1) Gaya hidup "gaul" menjadi trend remaja Muslimah saat ini. Hal ini sebagai cerminan adanya kolaborasi antara tuntunan ajaran agama dengan budaya pop.

(2) Globalisasi media massa turut memengaruhi gaya hidup remaja Muslimah. Hal ini dapat dilihat dari banyaknya tayangan-tayangan atau informasi yang disampaikan media massa dengan lebih mengedepankan budaya pop.

(3) Proses pembelajaran ala "madrasah" atau "pesantren" rumah yang, berdasarkan syariat Islam secara benar, dapat dijadikan upaya untuk mengeliminasi pengaruh dari budaya pop yang sedang trend, sehingga jadilah Muslimah yang gaul namun tidak ke luar dari syariat yang diajarkan Islam.

\subsection{Saran}

(1) Bagi para pengelola media massa, agar lebih bijaksana dalam menyampaikan informasi (pesan), karena apa yang ditampilkan oleh 
media akan ditiru oleh khalayaknya (remaja Muslimah) kita.

(2) Bagi para pendidik, disarankan untuk memperbanyak pembelajaran budi pekerti.

(3) Untuk para orangtua, hendaknya menjadikan rumah menjadi tempat proses pembelajaran ala "madrasah" atau "pesantren".

(4) Bagi para peminat studi budaya (culture studies), disarankan untuk menelaah masalah gaya hidup dikalangan anak muda atau remaja melalui penelitian.

\section{Daftar Pustaka}

Al-Banna, Hasan. 2004. Jangan Salah Gaul. Penerjemah Dwi Ratnasari, Yogyakarta: Diva Press.

Barker, Chris. 2005. Cultural Studies: Teori dan Praktek. Penerjemah Tim Kunci Cultural Studies Center. Yogyakarta: Bentang.

Budiman, Hikmat. 2002. Lubang Hitam Kebudayaan. Yogyakarta: Kanisius.
Chaney, David. 1996. Lifestyles: Sebuah Pengantar Komprehensif. Penerjemah Nuraeni. Yogyakarta: Jalasutra.

Fiske, John. 1990. Cultural and Communication Studies. Penerjemah Yosal Iriantara dan Idi Subandi. Yogyakarta: Jalasutra.

Ibrahim, Idi Subandy. 1996. Lifestyle Ecstacy: Kebudayaan Pop dalam Masyarakat Komoditas Indonesia. Yogyakarta: Jalasutra.

Kaina. 2004. Shopaholic Woman: Gaya Hidup dan Kenikmatan Berbelanja. Yogyakarta: Enigma Publishing.

Rakhmat, Jalaluddin. 1996. Psikologi Komunikasi: Edisi Revisi. Bandung: Remaja Rosdakarya.

Strinati, Dominic. 2004. Popular Culture: Pengantar Menuju Teori Budaya Populer. Penerjemah Abdul Mukhid. Yogyakarta: Bantang.

Susanto, A.B. 2001. Potret-Potret Gaya Hidup Metropolis. Jakarta: Penerbit Buku Kompas.

Tiar. 2004. Dialog Interaktif PSIA, www.gontor.or.id 
